\title{
Assessment of Livestock Loss Factors in the Western Serengeti, Tanzania
}

\author{
J. W. Nyahongo ${ }^{1}$ and E. Røskaft ${ }^{2}$ \\ ${ }^{1}$ The University of Dodoma, Dodoma, \\ 2Department of Biology, Norwegian University for Science \\ and Technology (NTNU), Realfagbygget \\ Centre for Advanced Study, Oslo, \\ ${ }^{1}$ Tanzania \\ ${ }^{2}$ Norway
}

\section{Introduction}

Diseases have been documented to be responsible for high loss in livestock production in sub-Saharan Africa (Gifford-Gonzalez, 2000). Historically, diseases have been the factor delaying the introduction of cattle-based economies by as much as one thousand years after the first appearance of small livestock in both eastern and southern Africa (GiffordGonzalez, 2000). Diseases that frequently are fatal to livestock production (especially cattle) in sub-Saharan Africa include wildebeest-derived Malignant Catarrhal Fever (MCF), East Coast Fever (ECF), Foot and Mouth Diseases (FMD), worms (helminthes), Rift Valley Fever (RVF), rinderpest, anthrax as well as trypanosomiasis (Kock, 2003; Thomson et al., 2003). Livestock diseases have economical consequences on livestock husbandry at two levels; 1) at the national and local level, the diseases are responsible for direct loss due to mortality or indirectly through lowered production and/or the cost of treatment and prevention (Perry et al., 2002; Kock, 2003). 2) At a global level diseases may affect any opportunity for export of livestock and livestock products between regions or continents, jeopardizing the exchange of products for foreign currency (Kock, 2003; OIE, 2003).

Because of negative attitudes of livestock keepers towards wild carnivores, they often claim wild carnivores being responsible for losses of livestock despite the severe impact of diseases (Mwangi, 1997; Rasmussen, 1999). However, several other factors as theft, drought and poor livestock husbandry may equally cause significant livestock loss (Ogada et al., 2003). The high price received for livestock in livestock auctions, make theft a lucrative business. In Africa theft may increase with the number of animals the household own, because it may be difficult to notice a loss of one or a few animals in a group of several hundred individuals. Moreover, livestock theft may vary with season or between years. During the rainy season, it may be easy to follow the tracks the stolen animal has left behind to the destination. The night with a full moon may not be conducive for livestock raiders because it is possible for livestock keepers to observe that livestock are missing in the night holding enclosure from the household living quarters. In some areas outside Africa, 
livestock theft has been considered a significant rural crime (WASDA, 2007). Drought may affect livestock directly by reducing the available food and water; hence animals may easily succumb to diseases. Indirectly, drought is normally associated with famine which drives the livestock keepers to trade some individuals to buy food.

The level of livestock depredation may intentionally be exaggerated to attract public attention and/or to mask effects of poor livestock management (Nabane, 1995; Infield, 1996; Nabane, 1996). Such negative attitudes towards carnivores due to perceived levels of predation have been cited as a challenging issue in both wildlife conservation and rural development (Woodroffe, 2000). Conflicts between humans and wild carnivores have been well documented in different parts of the world (Røskaft et al., 2003; Treves \& Karanth, 2003; Treves et al., 2004; Røskaft et al., 2007). This conflict has resulted in direct persecution of carnivores to get rid of them close to human settlements (Mills \& Hofer, 1998; Woodroffe \& Frank, 2005), and resulted in a general dislike of such animals. For example, American citizens do not like wolves Canis lupus and coyotes C. latrans (Kellert, 1985). Likewise, sheep farmers in Norway show negative attitudes towards large carnivores (Kaltenborn et al., 1998; Vittersø et al., 1998; Kaltenborn et al., 1999; Røskaft et al., 2007). In some parts of Africa, similar negative attitudes towards carnivores have been reported (Lindsey et al., 2005; Kaltenborn et al., 2006; Holmern et al., 2007b). Livestock keepers in Africa have been reported to kill and poison carnivores to reduce the perceived conflict over livestock depredation (Stuart et al., 1985; Berry, 1990; Holekamp \& Smale, 1992).

The aim of this study was to assess the factors responsible for livestock loss in households in villages outside the western parts of Serengeti National Park, Tanzania. Specifically the contribution of diseases, theft, depredation and loss in grazing fields due to poor management were assessed.

\section{Methods}

\subsection{Study area}

Serengeti National Park (SNP) is situated west of Rift Valley. The western border is close to Lake Victoria while the northern edge borders Kenya (Fig. 1). The central part of SNP was designated as a game reserve in 1929. In 1940 hunting was banned and in 1951 it was declared a national park. The borders have been modified as the park expanded. In 1981 Serengeti was inscribed as a World Heritage Site. The park covers $14763 \mathrm{~km}^{2}$ and is the core of the Serengeti ecosystem that includes Ngorongoro Conservation Area, Maswa Game Reserve, Ikorongo-Grumeti Game Reserves and Loliondo Game Controlled Area, in Tanzania as well as the Maasai Mara Natural Reserve in Kenya.

The study was conducted in four villages (Robanda, Nyamakendo, Nattambiso and Kowak) surrounding western Serengeti (Fig. 1). These villages currently suffer from the conflict between conservation priorities of the park and priorities of local communities (Hofer et al., 1996; Loibooki et al., 2002). This is a section of the Serengeti ecosystem that extends westward to Lake Victoria with a relatively high human population density (i.e. 70 people $/ \mathrm{km}^{2}$; growing at a rate of $2.5 \%$ per annum between 1988 and 2002, (URT, 2002). The majority of local communities along the boundaries of western Serengeti are subsistence 
farmers who keep livestock and practice crop production. Many of the farmers harvest natural resources inside the protected areas for domestic consumption. For instance, during the dry season, livestock keepers illegally graze and water their livestock in the protected areas (Nyahongo et al., 2005). In addition, illegal hunting within the protected areas is well documented and illegal bushmeat hunters may sell the illegally obtained meat to generate income (Arcese et al., 1995; Campbell \& Hofer, 1995; Loibooki et al., 2002; Nyahongo et al., 2005; Holmern et al., 2007a).

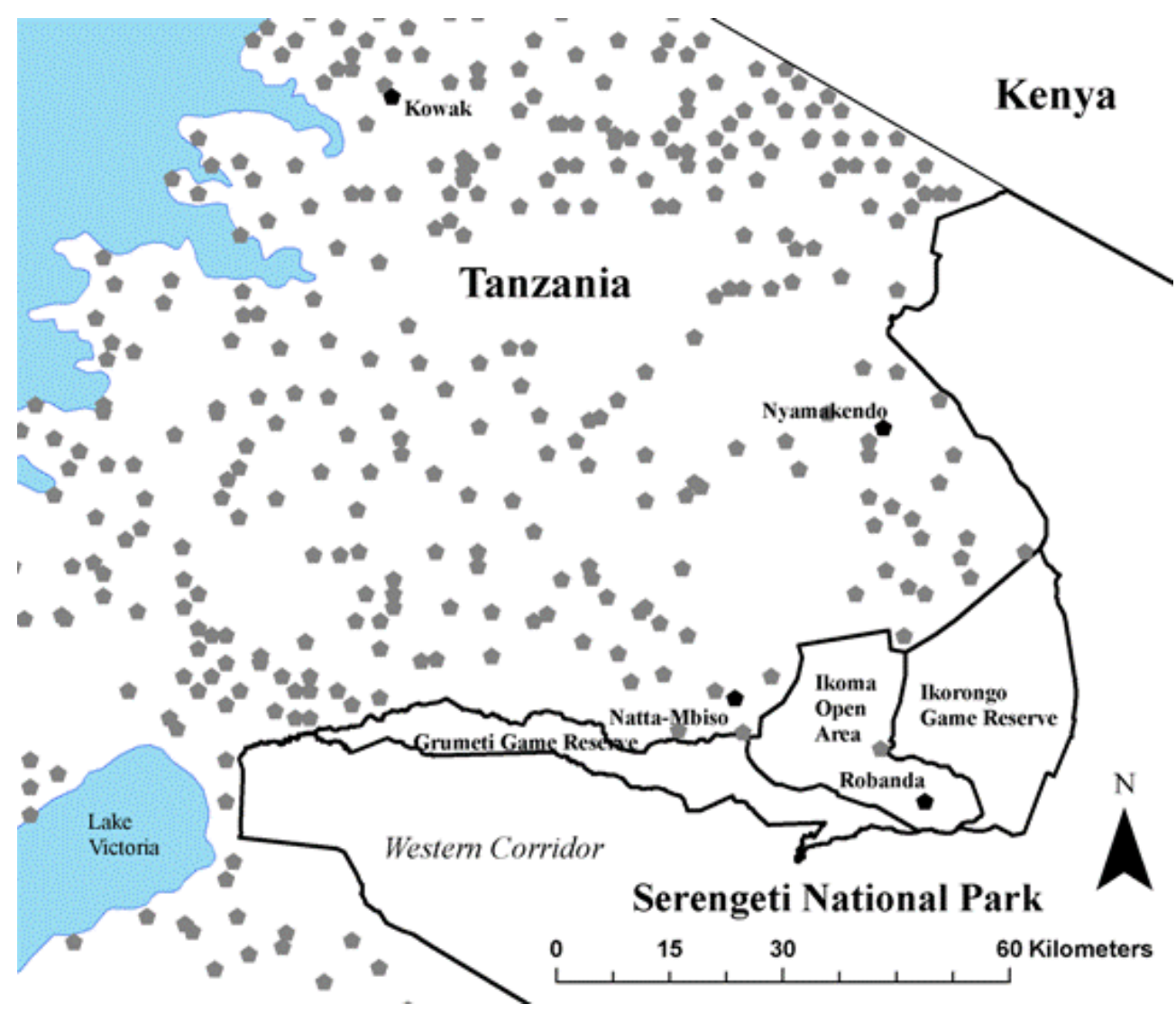

Fig. 1. Map of the western Serengeti showing the sampled villages.

\section{Data collection}

The current study was conducted between April and December 2006. Households were selected in the following four villages; Robanda, Nyamakendo, Nattambiso and Kowak. The first three villages were within $10 \mathrm{~km}$ from the boundary of the park while Kowak village was located about $80 \mathrm{~km}$ from the park. Households were selected randomly according to household lists in the villages. For practical reasons (livestock counting time), we omitted household with more than 200 individual cattle, goats or sheep because 
it was difficult to count the animals each time. January, February and March 2006 were spent in the villages to introduce researchers to livestock keepers and to establish baseline data on livestock numbers per selected household. Livestock owners were informed about the essence of this study and were assured that the data was only collected for research purpose and not for other purposes like baseline data for setting livestock levels by the government. After recording the baseline data (i.e. initial numbers of livestock per selected household), we appointed enumerators. Enumerators were recording any livestock that died due to diseases, were lost while grazing in the field (hereafter referred to as poor management), those which were stolen or were depredated. In addition they recorded livestock that were slaughtered. The gain of livestock recorded included newborn calves, bought or paid as dowry. While enumerators were collecting data on a daily basis, the researchers visited each household after every three months to recount the animals in order to cross check the data that enumerators collected. This was due to the fact that a researcher was also doing some questionnaire surveys in the area. Furthermore, livestock owners were asked about the livestock status during the past three months. Livestock were either counted in the morning before being sent out for grazing (normally 2 to $3 \mathrm{~km}$ away from the night holding enclosures) or in the evening when they were brought back to the night holding enclosures. The counting rate was 15 to 20 households per day and we spent one week in each village.

All livestock were prized according to matured livestock because market prices for livestock are only set for mature animals. This allowed us to be able to calculate the mean cost of livestock loss causes per household per year.

\section{Statistical analyses}

All analyses were performed using SPSS 16 statistical package. Non-parametric statistics were applied to test differences among the loss factors.

\section{Results}

\subsection{Causes of livestock gain and loss}

Mean household livestock and the subsequent costs or benefits in monetary terms for the current values of livestock species in each village are summarized in Tables 1 and 2.

Regardless of household locality, various loss causes affected livestock differently (cattle: Friedman test, $\chi^{2}=233.7, \mathrm{df}=3, \mathrm{n}=182, \mathrm{p}<0.001$; goats: Friedman test, $\chi^{2}=134.1 \mathrm{df}=3, \mathrm{n}$ $=155, \mathrm{p}<0.001$; sheep: Friedman test, $\chi^{2}=81.3$, df $=3, \mathrm{n}=123, \mathrm{p}<0.001$, Fig. 2). Furthermore, mean number of cattle and goats sold per household was higher than the number slaughtered (cattle: Wilcoxon sign rank test, $Z=-7.24, \mathrm{n}=182, \mathrm{p}<0.001$; goats: Wilcoxon sign rank test, $\mathrm{Z}=-3.214, \mathrm{n}=155, \mathrm{p}=0.001$ ) but this was not the case for sheep (Wilcoxon sign rank test, $\mathrm{Z}=-0.70, \mathrm{n}=123, \mathrm{p}=0.484$ ). In all households, new born calves, and not animals that were bought or paid as dowry, was the significant source of replenishment of livestock numbers (cattle: Wilcoxon sign rank test, $Z=-8.54, \mathrm{n}=182$, $\mathrm{p}<$ 0.001; goats: Wilcoxon sign rank test, $\mathrm{Z}=-8.38, \mathrm{n}=155, \mathrm{p}<0.001$; Sheep: Wilcoxon sign rank test, $\mathrm{Z}=-7.56, \mathrm{n}=123, \mathrm{p}<0.001)$. 


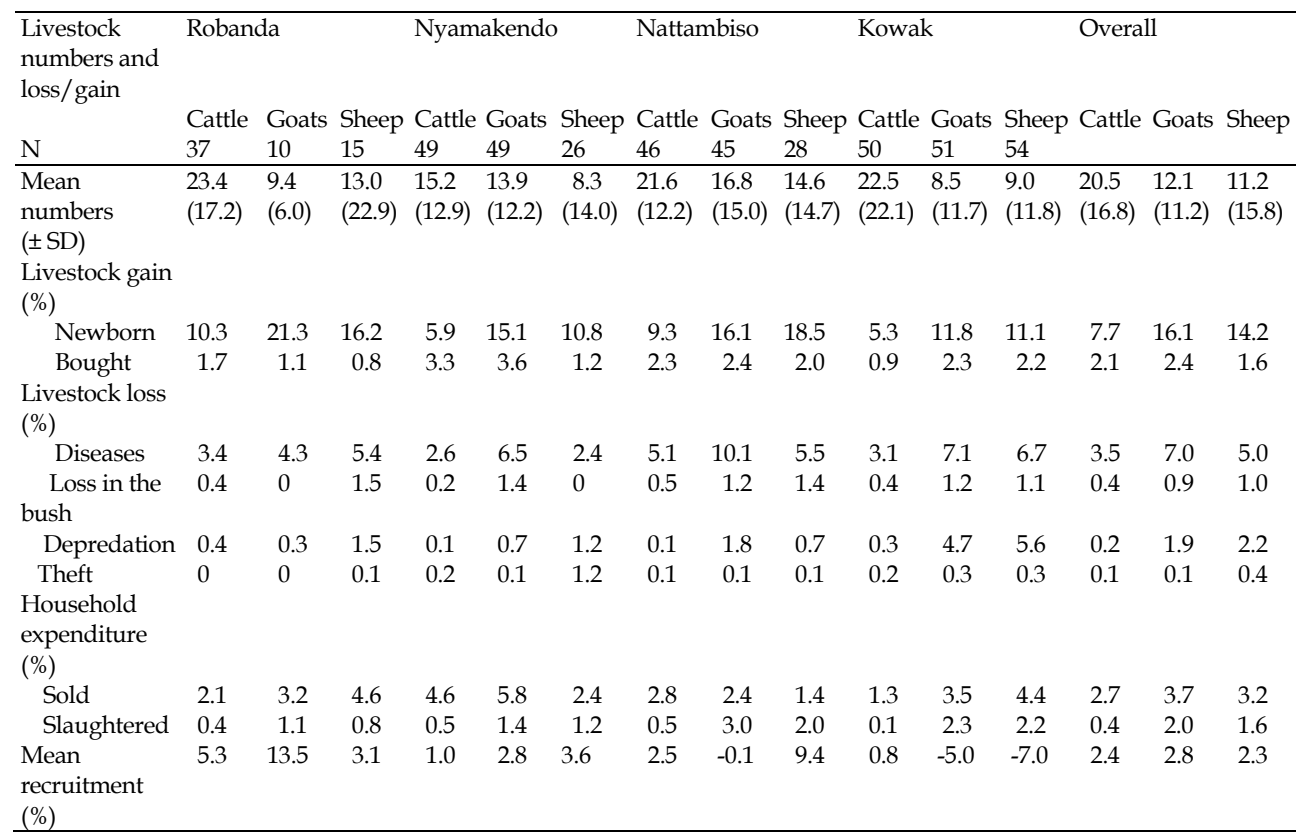

Note: \% means the percentage of the total livestock per village.

Table 1. Mean number of livestock per household and proportion of livestock loss or gain causes (livestock loss causes: diseases, loss in the bush (poor management while grazing), depredation and theft; livestock gain: newborn and bought/paid as dowry; household expenditure: sold and slaughtered for meat)

\subsection{Comparison of livestock loss causes among villages}

Overall, the mean numbers of livestock that were depredated was higher in Kowak village (about $80 \mathrm{~km}$ from the park boundary) than in villages that were close to the park boundary (Nattambiso, Nyamakendo and Robanda) (Kruskal-Wallis, $\mathrm{H}=14.52, \mathrm{df}=3, \mathrm{p}=0.002$, Kowak: rank $=252, \mathrm{n}=156$, Nattambiso: rank $=223.6, \mathrm{n}=119$, Nyamakendo: rank $=211.7, \mathrm{n}$ $=123$, Robanda: rank $=225.8, \mathrm{n}=62$ ). However, the difference among species that were depredated among villages was not statistically significant (Cattle: $p=0.09$, Goat: $p=0.113$, Sheep: $\mathrm{p}=0.119$ ). In all livestock depredation events spotted hyena Crocuta crocuta was the only carnivore reported to be responsible for livestock killing.

Mean number of cattle that died of diseases differed significantly among the villages (Kruskal-Wallis, $\mathrm{H}=17.07, \mathrm{df}=3, \mathrm{p}=0.001$ ). Furthermore, the difference in mean number of cattle that were stolen among villages was almost significant (Kruskal-Wallis, $\mathrm{H}=7.12$, $\mathrm{df}=$ $3, p=0.068)$. The remaining cattle loss causes did not differ significantly among villages $(p>$ 0.09 for all cases).

Loss causes in goats did not differ significantly among the four villages ( $p>0.076$ for all cases). However, for sheep, loss due to diseases and poor management differed significantly among the villages (Kruskal-Wallis, $\mathrm{H}=9.10, \mathrm{df}=3, \mathrm{p}=0.028$ and $\mathrm{H}=8.85, \mathrm{df}=3, \mathrm{p}=0.031$, 
respectively), while theft and depredation on livestock did not differ among the four villages ( $p>0.118$ for all cases).

\subsection{Comparison of livestock loss causes among livestock species}

Generally, regardless of distance from the park boundary, mean number of livestock species that were sold, slaughtered for food and that were killed by spotted hyenas differed significantly between livestock species (sold: Kruskal-Wallis, $\mathrm{H}=10.82, \mathrm{df}=2, \mathrm{p}=0.005$; slaughtered: Kruskal-Wallis, $\mathrm{H}=17.09, \mathrm{df}=2, \mathrm{p}<0.001$; predated: Kruskal-Wallis, $\mathrm{H}=$ $14.01, \mathrm{df}=2, \mathrm{p}=0.001$ ). Households sold more cattle (mean rank $=248.5$ ) than goats (mean rank $=231.4$ ) or sheep (mean rank $=202.7)$. However, households slaughtered more goats for food (mean rank $=249.6$ ) than sheep (mean rank $=243.2)$ or cattle (mean rank = 205.6). In contrast, sheep were more frequently killed by spotted hyenas (mean rank $=246.6$ ) than goats or cattle (goat: mean rank $=241.1$; cattle: mean rank $=210.6$ ). The remaining loss causes did not differ significantly among species ( $\mathrm{p}>0.151)$.

\begin{tabular}{|c|c|c|c|c|c|c|c|c|c|c|c|c|c|c|c|}
\hline \multirow{2}{*}{$\begin{array}{l}\text { Livestock } \\
\text { numbers } \\
\text { and } \\
\text { loss/gain }\end{array}$} & \multicolumn{3}{|c|}{ Robanda } & \multicolumn{3}{|c|}{ Nyamakendo } & \multicolumn{3}{|c|}{ Nattambiso } & \multicolumn{3}{|c|}{ Kowak } & \multicolumn{3}{|c|}{ Overall values (US\$) } \\
\hline & Cattle & Goats & Sheep & Cattle & Goats & Sheep & Cattle & Goats & Sheep & Cattle & Goats & Sheep & Cattle & Goats & Sheep \\
\hline $\begin{array}{l}\text { Mean } \\
\text { value of } \\
\text { livestock } \\
\text { Livestock } \\
\text { gain } \\
\text { values } \\
\text { (US\$) }\end{array}$ & 1872.0 & 188.0 & 260.0 & 1216.0 & 278.0 & 166.0 & 1728.0 & 336.0 & 292.0 & 1800.0 & 170.0 & 180.0 & 1654.0 & 243.0 & 224.0 \\
\hline Newborn & 192.8 & 40.0 & 42.1 & 71.7 & 42.0 & 17.9 & 160.7 & 54.1 & 54.0 & 95.4 & 20.1 & 20.0 & 130.1 & 39.1 & 33.5 \\
\hline $\begin{array}{c}\text { Bought } \\
\text { Livestock } \\
\text { loss (US\$) }\end{array}$ & 31.8 & 2.1 & 2.1 & 40.1 & 10.0 & 2.0 & 39.7 & 33.9 & 5.8 & 16.2 & 3.9 & 4.0 & 31.9 & 12.5 & 3.5 \\
\hline Disease & 63.6 & 8.1 & 14.0 & 31.6 & 18.1 & 4.0 & 88.1 & 10.1 & 16.1 & 55.8 & 12.1 & 12.1 & 59.8 & 12.1 & 11.6 \\
\hline $\begin{array}{l}\text { Depreda- } \\
\text { tion }\end{array}$ & 7.5 & 0.6 & 3.9 & 1.2 & 1.9 & 2.0 & 1.7 & 6.0 & 2.0 & 5.4 & 8.0 & 10.1 & 4.0 & 4.1 & 4.5 \\
\hline $\begin{array}{l}\text { Loss in } \\
\text { the bush }\end{array}$ & 7.5 & 0 & 3.9 & 2.4 & 3.9 & 0 & 8.6 & 4.0 & 4.1 & 7.2 & 2.0 & 2.0 & 6.4 & 2.5 & 2.5 \\
\hline $\begin{array}{l}\text { Theft } \\
\text { Household } \\
\text { expendi- } \\
\text { ture (US\$) }\end{array}$ & 0 & 0 & 0.3 & 2.4 & 0.3 & 2.0 & 1.7 & 0.3 & 0.3 & 3.6 & 0.5 & 0.5 & 1.9 & 0.3 & 0.8 \\
\hline Sold & 39.3 & 6.0 & 12.0 & 55.9 & 16.1 & 4.0 & 48.4 & 8.1 & 4.1 & 23.4 & 5.9 & 7.9 & 41.8 & 9.0 & 7.0 \\
\hline $\begin{array}{l}\text { Slaughte- } \\
\text { red }\end{array}$ & 7.5 & 6.0 & 2.1 & 6.1 & 3.9 & 2.0 & 8.6 & 10.1 & 5.8 & 1.8 & 3.9 & 4.0 & 6.0 & 6.0 & 4.5 \\
\hline
\end{tabular}

Note: Mean local market price of one cattle in the study area was US\$ 80, and for goat/sheep was US\$ 20 in 2006, (the prices were for mature animals).

Table 2. Cost and benefit implications of livestock loss and/or gain causes (US \$)

\subsection{Economic significance of livestock loss or gain causes}

In total, the mean economic value of livestock that households from four villages owned was TSh 3,181,500 (US\$ 2121) (sum of cattle, goats and sheep per household) and newborn 
calves per household were worth TSh 304,050 (US\$ 202.7). When the effect of livestock loss causes were pooled, diseases were responsible for TSh 124,500 (US\$ 83) per household, while wild carnivores caused TSh 18,900 (US\$ 12.6) per household. On average, the value of livestock sold per household was TSh 86,700 (US\$ 57.8). Livestock losses due to theft and poor management were TSh 21,600 (US\$ 14.4) while animals slaughtered for meat were worth TSh 24,750 (US\$ 16.5) per household. Each village cost-benefit analysis of each loss or gain causes is summarized in Table 2.
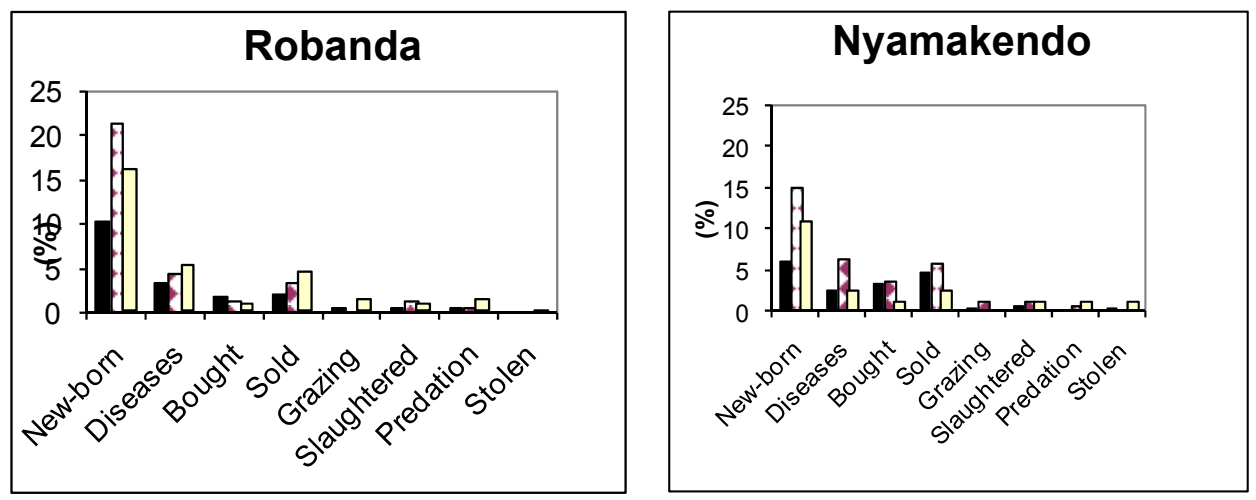

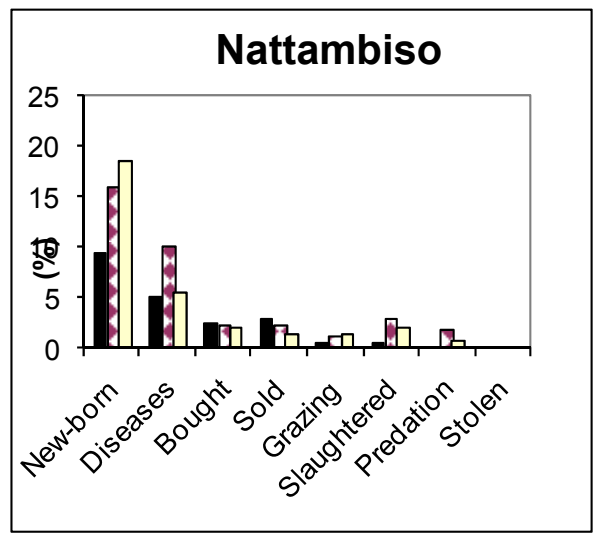

Loss/gain factors

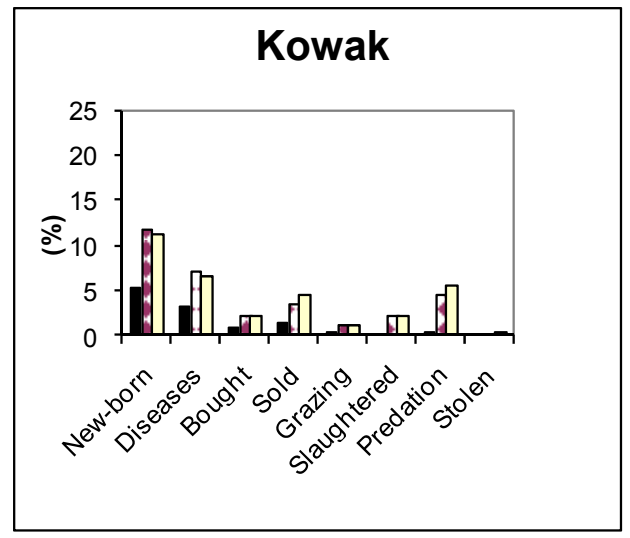

Loss/gain factors

Note: Solid black column represent cattle; column with dotted represent goat and open column represent sheep

Fig. 2. Overall livestock population dynamics (loss and gain) in four villages recorded from April to December 2006. 


\section{Discussion}

The results of this study suggest that diseases are responsible for higher livestock loss than any other cause within and among villages. However, sheep loss due to diseases and poor management differed significantly among the villages. Mean number of cattle and goats sold was higher than the number slaughtered in all villages. In all households, new born calves were the most significant source of replenishment of livestock numbers. Livestock species that were sold, slaughtered for food and killed by spotted hyenas differed significantly between species whereof goats and sheep were more frequently slaughtered for food than cattle.

Disease is the major factor responsible for livestock loss in sub-Saharan Africa (GiffordGonzalez, 2000). This factor alone, although not recognized by farmers in Africa (Mwangi, 1997), was responsible for a loss of US\$ 83.5 per household during the nine months study period. When this figure is compared to the average annual cash income per household in the western Serengeti (US\$ 140, (Borge, 2003), loss because of diseases were responsible for $59.6 \%$ of the average annual household income in the target villages. On average, diseases contributed 5.1 times more of livestock loss than depredation. This observation is consistent with previous studies in the same area when farmers were requested to rank major factors of livestock loss (Nyahongo, 2004). Livestock keepers may not observe the direct effect of diseases on their livestock production due to the fact that sick animals may be slaughtered and used as food or sold to neighbors while carnivores often consume all edible parts of a kill, leaving nothing for human consumption. Moreover, diseases often kill a larger number of new born calves than adults (Nyahongo, pers. Obs, 2006). Livestock keepers may not observe this as an important loss because the capital investment in terms of veterinary services, feeding or grazing time and/or output in terms of meat or money (when sold) is relatively much lower for new-born calves than for adults. Moreover, due to poor livestock management records, livestock keepers may not be able to know how many livestock they loose to diseases within a specific period of time. Most of the household in this study did not keep any record showing their number of livestock, new born or even the last time animals were treated and the costs implication. In contrast, when a predator breaks into the livestock enclosures, usually at night (Nyahongo, 2004; Kolowski \& Holekamp, 2006; Holmern et al., $2007 b$ ) it may kill several adult animals which may result in serious economic consequences for the livestock keepers. However, since the compensation scheme that may offset some of the costs are always lacking in Tanzania, negative attitudes towards carnivores may have developed among farmers, which have resulted in retaliatory killing practices of carnivores in or close to village proximities (Holekamp \& Smale, 1992; Ogada et al., 2003; Dickman, 2005; Frank et al., 2005; Graham et al., 2005; Holmern et al., 2007b).

A relatively higher number of sheep and goats were depredated by spotted hyena in the village that was located furthest away from the park boundary. This suggests that even in open areas with high anthropogenic activities, there are still some refuges for some large carnivores like spotted hyenas. This observation suggests a need of including a section in the current wildlife policy to accommodate the protection of wildlife in anthropogenic dominated areas. For instance, certain carnivore species such as spotted hyenas have the ability to commute up to $80 \mathrm{~km}$ (Hofer \& East, 1993) allowing them to forage even in villages located far from the protected areas. The findings of the present study is inconsistent with the idea that high depredation is always highest close to reserves 
boundaries (Mwangi, 1997). However, as Woodroffe (2000) puts it, behavioral plasticity of certain carnivore species facilitate their adaptive adjustment to an increasingly precarious lifestyle in proximity to human, a fact that was reported for spotted hyenas in the Maasai Mara ecosystem (Boydston et al., 2003). Thus, we cannot conclude that the spotted hyenas reported at the distant villages commuted from Serengeti or were resident to the village areas.

Analyses of our data suggests that cattle are kept to solve household needs that require relatively huge amounts of money while goats and sheep are kept to tackle small household needs and/or are slaughtered to provide meat protein to the household. This might be due to the fact that the economic value of one cattle is equivalent to about four goats or sheep. These ideas are supported by comparing the number of cattle, goats and sheep that were slaughtered and those that were sold. The proportions of cattle slaughtered were far less than those sold by households in the study villages (Table 1, Fig 2).

Variables like available water and grazing land, weather, market prices of meat (that could lead to elevated theft rate), and animal population dynamics in the villages and in the protected areas adjacent to village areas, diseases occurrence, may, as the variables included in the analyses, show considerable between year variations. These confounding variables, which cannot be controlled for in a snap shot study like the present one, might have influenced the data we collected. For instance, death of livestock due to diseases may increase with drought or with rain intensity and duration, which cannot be precisely compared within a year because intensity of rain and duration of rain seasons may differ in different areas each year in Tanzania affecting pasture quality and available water for animals. Drought may also influence the number of livestock sold to buy food, because crop production in the country largely depends on rain. Weather, on the other hand may influence the survival of new born calves or may influence the level of depredation. Woodroffe and Frank (2005) observed that rate of livestock depredation by large carnivores increased with increasing rainfall. Exclusion of households with more than 200 animals might have further led to an underestimation of livestock loss because more death from disease (due to density dependent danger of infectious diseases), livestock depredation, theft and loss due to poor management in the grazing field may be expected to increase with an increase in livestock numbers.

\section{Conclusion}

The results from this study show that diseases are the major cause of livestock loss in villages surrounding SNP and that the levels of loss do not vary much among households in the western Serengeti. In contrast, livestock depredation by spotted hyena was relatively low, although it was relatively higher for goats and sheep in household at the most distant village. Likewise, poor management and theft that can be managed at household level causes livestock losses as well. However, at the household level, a single depredation event may cause a serious economic loss.

Livestock depredation may be higher in the areas with high human activities, which encourage wildlife managers, conservationists and wildlife ecologists to think deeply about livestock depredation along the gradient of distance from the park and the future conservation of the carnivores along the same gradient. 
This study suggest that local people would benefit from better education on animal husbandry practices and extension service to help them maintain the health of their livestock and to prevent theft and loss of livestock while grazing. We recommend that disease control and management should be integrated as part of the regional and national development programs to limit disease transmission between livestock and wildlife and even among livestock in the villages. Further studies on the types and epidemiology of diseases causing major livestock losses in the area should be conducted in order to design appropriate disease control measures.

\section{Acknowledgements}

The current study was funded by NORAD through the Ministry of Natural Resources and Tourism, Tanzania and was a part of the Tanzania Wildlife Research Institute (TAWIRI), Norwegian Institute for Nature Research (NINA) and Norwegian University for Science and Technology (NTNU) project called Biodiversity and Human Wildlife Interface in Western Serengeti. We acknowledge the financial support from the Norwegian Peace Corps and the Quota Programme Scheme (NORAD). We thank Commission for Science and Technology (COSTECH) and Tanzania National Parks (TANAPA) for granting permissions to the foreign researchers to work in Serengeti National Park. We thank T. Holmern and B. Stokke for their valuable comments during the preparation of the manuscript. Finally, we thank village leaders and our field assistants who in one way or the other contributed to this important task.

\section{References}

Arcese, P., Hando, J. \& Campbell, K. (1995) In Serengeti II. Dynamics, Managements, and Conservation of an Ecosystem. (eds A. R. E. Sinclair \& P. Arcese), pp. 506-533. University of Chicago Press, Chicago, Ill, USA.

Berry, H. (1990) The Lions of Etosha. Cat News, 13, 11-12.

Borge, A. (2003) Essays on the Economics of African Wildlife Utilization and Management. Norwegian University of Science and Technology.

Boydston, E. E., Kapheim, K. M., Watts, H. E., Szykman, M. \& Holekamp, K. E. (2003) Altered Behaviour in Spotted Hyenas Associated with Increased Human Activity. Animal Conservation, 6, 207-219.

Campbell, K. \& Hofer, H. (1995) In Serengeti II: Dynamics, Management and Conservation of an Ecosystem (eds A. R. E. Sinclair \& P. Arcese), pp. 534-570. The University of Chicago Press, Chicago, Ill.

Dickman, A. J. (2005) An Assessment of Pastoralist Attitudes and Wildlife Conflict in the RungwaRuaha Region, Tanzania with Particular Reference to Large Carnivores Oxford University.

Frank, L. G., Woodroffe, R. \& Ogada, M. O. (2005) In People and Wildlife Conflicts or Coexistence? (eds R. Woodroffe, S. Thirgood \& A. Rabinowitz), pp. 286-304. Cambridge University Press, Cambridge, UK.

Gifford-Gonzalez, D. (2000) Animal Disease Challenges to the Emergency of Pastoralism in Sub-Saharan Africa. Archaelogical Review, 17, 95-139. 
Graham, K., Beckerman, A. P. \& Thirgood, S. (2005) Human-Predator-Prey Conflicts: Ecological Correlates, Prey Losses and Patterns of Management. Biological Conservation, 122, 159-171.

Hofer, H., Campbell, K. L. I., East, M. L. \& Huish, S. A. (1996) In The Exploitation of Mammal Populations (eds J. Taylor \& N. Dunstone), pp. 117-146. Chapman and Hall, London, UK.

Hofer, H. \& East, M. L. (1993) The Commuting System of Serengeti Spotted Hyaenas - How a Predator Copes with Migratory Prey .2. Intrusion Pressure and Commuters Space Use. Animal Behaviour, 46, 559-574.

Holekamp, K. E. \& Smale, L. (1992) pp. 19-20. IUCN, SSC Hyena Specialist Group

Holmern, T., Muya, J. \& Røskaft, E. (2007a) Local Law Enforcement and Illegal Bushmeat Hunting Outside the Serengeti National Park, Tanzania. Environmental Conservation, 34, 55-63.

Holmern, T., Nyahongo, J. W. \& Røskaft, E. (2007b) Livestock Loss Caused by Predators Outside the Serengeti National Park, Tanzania. Biological Conservation, 135, 518-542.

Infield, M. (1996) In East African Livestock Conference, Small Ruminant Collaborative Research Support Program University of California, Entebe, Uganda.

Kaltenborn, B. P., Bjerke, T., Nyahongo, J. W. \& Williams, D. R. (2006) Animal Preferences and Acceptability of Wildlife Management Actions Around Serengeti National Park, Tanzania. Biodiversity and Conservation, 15, 4633-4649.

Kaltenborn, B. P., Bjerke, T. \& Strumse, E. (1998) Diverging Attitudes Towards Predators: Do Environmental Beliefs Play a Part? Human Ecology Review, 5, 1-9.

Kaltenborn, B. P., Bjerke, T. \& Vittersø, J. (1999) Attitudes Toward Large Carnivores Among Sheep Farmers, Wildlife Managers, and Research Biologists in Norway. Human Dimension and Wildlife, 4, 57-73.

Kellert, S. R. (1985) Public Perceptions of Predators, Particularly the Wolf and Coyote. Biological Conservation, 31, 167-189.

Kock, R. A. (2003) PACE Eridemiology Unit, AU/IBAR, Nairobi, Kenya.

Kolowski, J. M. \& Holekamp, K. E. (2006) Spatial, Temporal, and Physical Characteristics of Livestock Depredations by Large Carnivores along a Kenyan Reserve Border. Biological Conservation, 128, 529-541.

Lindsey, P. A., du Toit, J. T. \& Mills, M. G. L. (2005) Attitudes of Ranchers Towards African Wild Dogs I: Conservation Implications on Private Land. Biological Conservation, $125,113-121$.

Loibooki, M., Hofer, H., Campbell, K. L. I. \& East, M. L. (2002) Bushmeat Hunting by Communities Adjacent to the Serengeti National Park, Tanzania: The Importance of Livestock Ownership and Alternative Sources of Protein and Income. Environmental Conservation, 29, 391-398.

Mills, G. \& Hofer, H. (1998) (ed I. S. H. S. Group), Information Press, Oxford, UK.

Mwangi, N. S. (1997) A Cost-Benefit Analysis of Livestock Predation on the Group Ranches in the Dispersal Areas of Maasai Mara National Reserve, Kenya. Moi University.

Nabane, N. (1995) In Wildlife and Development Series International Institute for Environment and Development, London, UK.

Nabane, N. (1996) Zimbabwe: Whose CAMPFIRE? Gender Issues in Community-Based Conservation: The Case of Masoka Village. The Rural Extension Bulletin: Special Issue on Community Conservation, 10, 46-49. 
Nyahongo, J. W. (2004) Impact of Human Activities on Carnivore Populations in the Western Serengeti Ecosystem. University of Dar-es-Salaam.

Nyahongo, J. W., East, M. L., Mturi, F. A. \& Hofer, H. (2005) Benefits and Costs of Illegal Grazing and Hunting in the Serengeti Ecosystem. Environmental Conservation, 32, 326-332.

Ogada, M. O., Woodroffe, R., Oguge, N. O. \& Frank, L. G. (2003) Limiting Depredation by African Carnivores: the Role of Livestock Husbandry. Conservation Biology, 17, 1521-1530.

OIE (2003) Office International des Epizooties, Paris, France.

Perry, B. D., Randolph, T. F., McDermott, J. J., Sones, K. R. \& Thornton, P. K. (2002) pp. 148. International Livestock Research Institute (ILRI), Nairobi, Kenya.

Rasmussen, G. S. A. (1999) Livestock Predation by the Painted Hunting Dog Lycaon pictus in a Cattle Ranching Region of Zimbabwe: a Case Study. Biological Conservation, 88, 133-139.

Røskaft, E., Bjerke, T., Kaltenborn, B. P., Linnell, J. D. C. \& Andersen, R. (2003) Patterns of Self-reported Fear Towards Large Carnivores Among the Norwegian Public. Evolution and Human Behavior, 24, 184-198.

Røskaft, E., Händel, B., Bjerke, T. \& Kaltenborn, B. P. (2007) Human Attitudes Towards Large Carnivores in Norway. Wildlife Biology, 13, 172-185.

Stuart, C. T., MacDonald, I. A. W. \& Mills, M. G. L. (1985) History, Current Status and Conservation of Large Mammalian Predators in Cape Province, Republic of South Africa Biology Conservation, 31, 7-19.

Thomson, G. R., Vosloo, W. \& Bastos, A. D. S. (2003) Foot and Mouth Disease in Wildlife. Virus Research, 19, 145-161.

Treves, A. \& Karanth, K. U. (2003) Human-carnivore Conflict and Perspectives on Carnivore Management Worldwide. Conservation Biology, 17, 1491-1499.

Treves, A., Naughton-Treves, L., Harper, E. K., Mladenoff, D. J., Rose, R. A., Sickley, T. A. \& Wydeven, A. P. (2004) Predicting Human-carnivore Conflict: a Spatial Model Derived from 25 Years of Data on Wolf Predation on Livestock. Conservation Biology, 18, 114-125.

URT (2002) (ed Tourism-Department), Ministry of Natural Resources and Tourism, Dar es Salaam, Tanzania.

Vittersø, J., Kaltenborn, B. P. \& Bjerke, T. (1998) Attachment to Livestock and Attitudes toward Large Carnivores among Sheep Farmers in Norway. Anthrozoös, 11, 210217.

WASDA (2007) Washington State Department of Agriculture, Seattle, WA, USA.

Woodroffe, R. (2000) Predators and People: Using Human Densities to Interpret Declines of Large Carnivores Animal Conservation, 3, 165-173.

Woodroffe, R. \& Frank, L. G. (2005) Lethal Control of African Lions (Panthera leo): Local and Regional Population Impacts. Animal Conservation, 8, 91-98. 


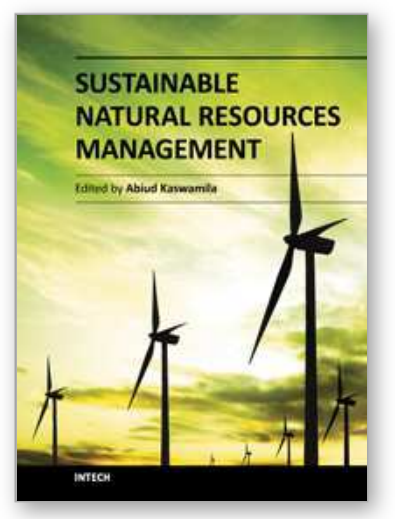

\author{
Sustainable Natural Resources Management \\ Edited by Dr. Abiud Kaswamila
}

ISBN 978-953-307-670-6

Hard cover, 166 pages

Publisher InTech

Published online 13, January, 2012

Published in print edition January, 2012

Natural resources conservation is one of the dilemmas currently facing mankind in both developed and the developing world. The topic is of particular importance for the latter, where the majority depend on terrestrial ecosystems for livelihood; more than one billion people live in abject poverty earning less than a dollar per day; more than 3.7 billion suffer from micronutrient deficiency and more than 800 million suffer from chronic hunger. Population increase, resource use conflicts, technological advancements, climate change, political doldrums, and unsustainable use and harvesting of resources have all put more pressure on natural resources leading to land degradation and poverty. To achieve a win-win situation, we need to change our mindset by thinking outside the box through advocating integrated and holistic approaches in managing our natural resources. This book presents a variety of sustainable strategies and/or approaches including use of GIS and Remote Sensing technologies, decision support system models, involvement of stakeholders in major decisions regarding use of natural resources, community level initiatives, and use of surveillance and monitoring mechanisms.

\title{
How to reference
}

In order to correctly reference this scholarly work, feel free to copy and paste the following:

J. W. Nyahongo and E. Røskaft (2012). Assessment of Livestock Loss Factors in the Western Serengeti, Tanzania, Sustainable Natural Resources Management, Dr. Abiud Kaswamila (Ed.), ISBN: 978-953-307-6706, InTech, Available from: http://www.intechopen.com/books/sustainable-natural-resourcesmanagement/assessment-of-livestock-loss-factors-in-the-western-serengeti-tanzania

\section{INTECH}

open science | open minds

\section{InTech Europe}

University Campus STeP Ri Slavka Krautzeka 83/A 51000 Rijeka, Croatia Phone: +385 (51) 770447 Fax: +385 (51) 686166 www.intechopen.com

\section{InTech China}

Unit 405, Office Block, Hotel Equatorial Shanghai No.65, Yan An Road (West), Shanghai, 200040, China 中国上海市延安西路65号上海国际贵都大饭店办公楼 405 单元 Phone: $+86-21-62489820$

Fax: +86-21-62489821 
(C) 2012 The Author(s). Licensee IntechOpen. This is an open access article distributed under the terms of the Creative Commons Attribution 3.0 License, which permits unrestricted use, distribution, and reproduction in any medium, provided the original work is properly cited. 